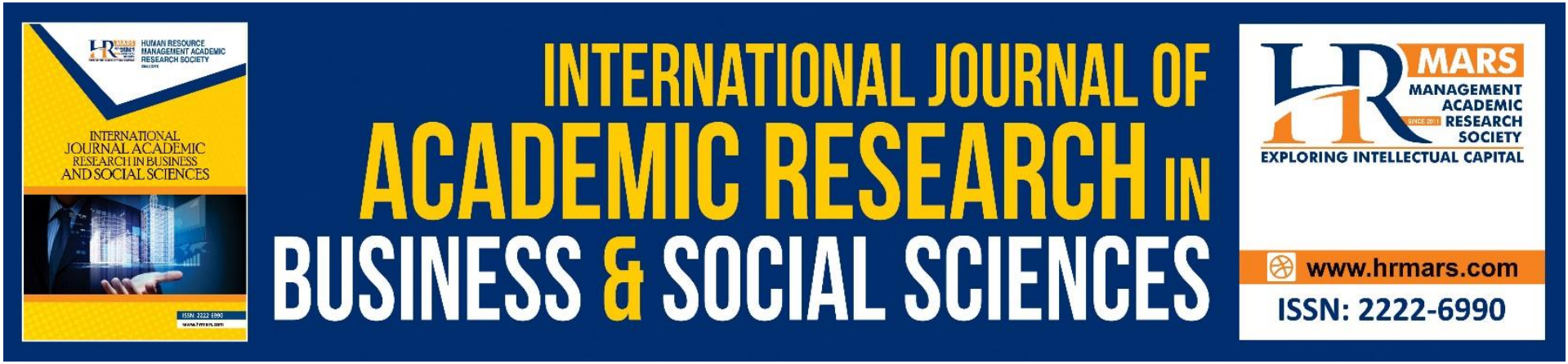

\title{
Understanding the Voter's Behavior as an Effort to Increase Publics' Political Participation in Indonesia
}

\author{
Yadi Satriadi, Sarina Yusuf, Roslan Ali
}

To Link this Article: http://dx.doi.org/10.6007/IJARBSS/v11-i2/9192 ～DOI:10.6007/IJARBSS/v11-i2/9192

Received: 11 December 2020, Revised: 16 January 2021, Accepted: 05 February 2021

Published Online: 25 January 2021

In-Text Citation: (Satriadi et al., 2021)

To Cite this Article: Satriadi, Y., Yusuf, S., \& Ali, R. (2021). Understanding the Voter's Behavior as an Effort to Increase Publics' Political Participation in Indonesia. International Journal of Academic Research in Business and Social Sciences, 11(2), 960-972.

Copyright: (c) 2021 The Author(s)

Published by Human Resource Management Academic Research Society (www.hrmars.com)

This article is published under the Creative Commons Attribution (CC BY 4.0) license. Anyone may reproduce, distribute, translate and create derivative works of this article (for both commercial and non-commercial purposes), subject to full attribution to the original publication and authors. The full terms of this license may be seen at: http://creativecommons.org/licences/by/4.0/legalcode

Vol. 11, No. 2, 2021, Pg. 960 - 972

http://hrmars.com/index.php/pages/detail/IJARBSS

JOURNAL HOMEPAGE

Full Terms \& Conditions of access and use can be found at http://hrmars.com/index.php/pages/detail/publication-ethics 


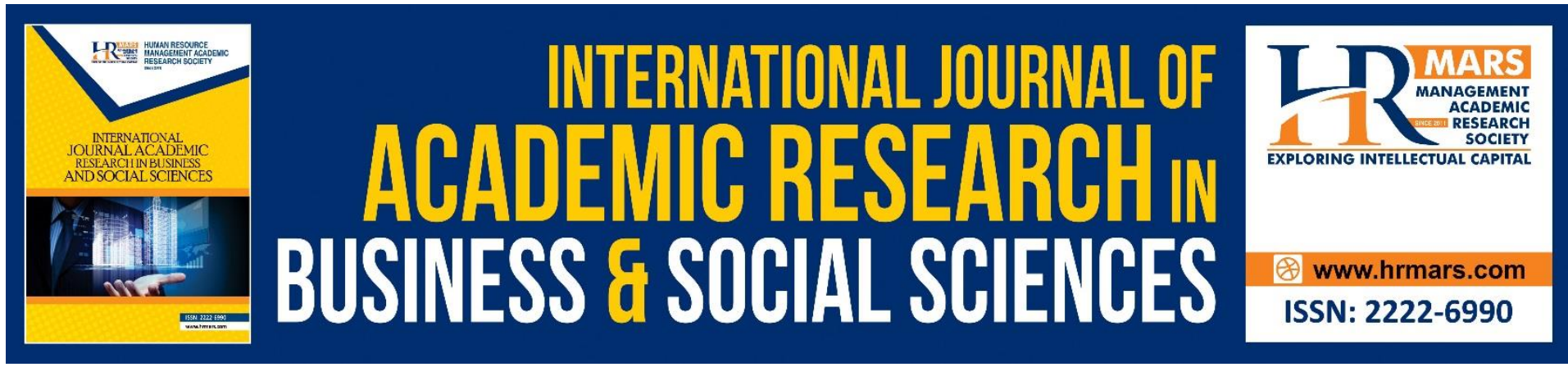

\title{
Understanding the Voter's Behavior as an Effort to Increase Publics' Political Participation in Indonesia
}

\author{
Yadi Satriadi, Sarina Yusuf, Roslan Ali \\ Department of Communication and Media, Faculty of Languages and Communication \\ Sultan Idris Education University, 35900, Perak, Malaysia
}

\begin{abstract}
This article is based on the reflection of voter's participation issue in determining their political choices on Indonesia's election momentum. The increasing number of political participation in abstention is an exciting issue to be studied in democratic countries. It is exciting because one of the benchmarks for the success of democracy is based on society's participation in elections. This article seeks to present a comprehensive overview of voter's behavior through various theoretical points of view. Literature review method is used in arranging this article. This article introduces the voter's behavior and a discussion of theoretical approaches to read the voter's behavior. This article focuses on the main findings of relevant theory and empirical research that provide insight related to the factors that cause voting behavior and their relations. This article concludes that people have different voting behaviors. Some voters vote based on sociological factors such as social communities, family, ethnicity, and religion and are also influenced by psychological factors such as identifying political parties, candidates, and issues.
\end{abstract}

Keywords: Voter's Behavior, Sociological Approach, Psychological Approach, Social Community, Psychological Factors.

\section{Introduction}

One of the most exciting questions regarding elections is not always about who is the winner but how the voting community makes their political decisions to vote the candidates (Antwi, 2018). Direct election is an implementation of the post-reform democratization process in 1998. According to Diamond, Linz, and Lipset (1990), one of the main conditions for a democratic political system government is political participation that involves as many people as possible in the fair and equitable elections. In line with what Diamond, Linz, and Lipset convey about the importance of political participation in democracy, Verba, Schlozman, and Brady (1995) in Mujani (2007) also state that publics' participation is the heart of democracy. From these experts' views, it can be concluded that publics' participation has a vital role in keeping democracy.

In the direct election, voters have an important position and role as a determinant of election results and the future government's direction. The election is a momentum for voters to 
determine whether a government will change or not, likewise with policies in all government sectors. Quoting Larry Diamond's statement (in Friedman, 2010), if you do not get the right government, it is very difficult to get other truths related to the government. Therefore, the study of how voters make choices in an election's momentum is interesting.

This paper will discuss voters' behavior of the Presidential election (PILPRES) in Indonesia. This study is conducted to look at voter's behavior based on their political participation in the three previous PILPRES periods, namely in 2004, 2009, and 2014. Data obtained from the General Election Commission of Republic Indonesia (KPU RI) by BBC News (2019) indicated that publics' political participation is decreasing from 2004 to 2014. This reduction can be seen in the number of abstaining voters. In 2004 PILPRES, there was $23.30 \%$ of abstaining voters. In 2009 PILPRES, there was $27.45 \%$ abstaining voters, and in 2014 PILPRES, the number of abstaining voters increased to $30.42 \%$. The data is not in line with the increasing number of voters. As explained by Putu Artha (who was a KPU commissioner) in kumparan.com (2018) that the number of the 2004 PILPRES Permanent voter's List (DPT) was 150.6 million, the 2009 PILPRES DPT was 176.3 million, and in 2014 PILPRES continued to increase by $7 \%$ or as many as 188.2 million voters. From the explanation above, the writer is interested in investigating the factors that cause voters to participate in using their voting rights in election.

\section{Voter's Behavior}

Voter's behavior is related to human behavior in the context of an election. Voter's behavior is the act of determining which political choice they feel is the most suitable or the most preferred to be chosen. Voting is defined as a series of personal actions in an election that can include participation in a campaign, participation in the election, and deciding who will be elected (Bratton, 2012). According to Jack C Plano (1985) in Sudaryanti (2008), voter's behavior is a study that focuses on the tendency of people's choices in elections and their reasons for making the choices.

Another definition, from Surbakti (2010), states that voter's behavior is an activity to choose or not as a form of public' participation in elections. Voter's behavior is the publics' participation in general elections and contributing to political decisions in general elections. Participation or involvement in general elections is a form of political participation. It refers to an expert's opinion, which states that political participation, including participation in general elections, is the act of a society that is consciously carried out to influence publics' decisions

Voters are Indonesian citizens aged 17 years old and older or already married. In each election, voters are registered through data collection conducted by officers appointed by the election organizer (Pahmy, 2010). Besides, Firmanzah (in Efriza, 2012) explains that voters are defined as all parties who are become the primary goal of political candidates to influence and convince to get support and then cast their votes for the candidates concerned. Voters, in this case, can be either constituents or ordinary people. Constituents are a group of people who feel represented by a particular ideology, manifested in political institutions such as parties.

The studies of voter's behavior in elections showed that vote decisions do not occur in a vacuum or happen by themselves. Instead, decision making is based on a person life experiences. Many factors influence voters' choice. As stated by Prysby and Scavo 1993 (in Hazarika, 2015), the study showed that voters can determine their vote based on one or more considerations, such as (1) the performance of the government in power, (2) the personality of the candidate, (3) the voter position or orientation on specific issues, (4) party affiliation, 
(5) economic circumstances, and (6) identity or ethnic background of the candidate. Both short-term and long-term effects shape these considerations. Short-term influences are specific to a particular election and are prone to significant changes from one election to the next. For example, it includes economic circumstances, government performance, or the personality of a candidate. However, other factors, such as loyalty to parties, are considered more stable in the long term (Prysby \& Scavo 1993 in Hazarika, 2015).

According to Surabakti (2007), Voter's behavior is determined by seven different and separate cognitive domains, namely:

Social imagery; Social imagery shows candidates or parties' stereotypes to attract voters by creating associations between candidates or parties and specific segments of the society. The social image can occur based on many factors, including demography, socio-economy, culture, ethnicity and political ideology.

Emotional feelings; emotional feelings are a dimension that emanates from a contestant or candidate that is shown by the political policies on offer.

Candidate personalities; Candidate personalities refer to important personal traits that considered as a candidate's character.

Current events; Current events refer to events, issues, and policies that develop ahead of and during a campaign.

The personal event; Personal events refer to private life and events that a candidate has personally experienced, such as sex scandals, business scandals, being a victim of a particular regime, becoming a figure in struggle, participating in a war, and so on.

Epidemics issues; Epidemics are specific electoral issues that can trigger a voter's curiosity about new things.

Then based on the behavior, Eep Syaifullah (in Efriza, 2012) stated that voters are categorized into four main groups, namely: (1) Calculative Rational Voters are voters who base their political decisions on rational and logical calculations, (2) Primordial Voters are voters who determine their political choices because of primordial reasons such as reasons of religion, ethnicity and descent, (3) Pragmatic voters are voters who are predominantly influenced by estimates of profit and loss, (4) Emotional Voters are individuals or groups of voters who base their political choices on feelings.

Voter's behavior approach

In the study of voter's behavior, three approaches have been the basis for reading voter's behavior, namely: The Columbia Study, The Michigan Model, Rational Choice, each well known as a sociological approach, the psychological approach, and the rational choice approach (Bartels, 2012). Of the three approaches, in this study, two approaches will be used to read voter's behavior, namely the sociological approach and the psychological approach.

A sociological approach was pioneered by Paul Lazarsfeld, Bernard Berelson, and Hazel Gaudet from the Bureau of Applied Social Research at Columbia University, so this approach is known as Mazhab Columbia. Lazarsfeld and his colleagues at Columbia School surveyed 600 voters in Erie County, Ohio, during the 1940 United States presidential election. Participants were interviewed seven times over the seven months of the presidential campaign to decide if there were voters who changed their decision. In the study, only 54 study respondents changed their choices throughout the campaign (Antwi, 2018).

This research was made to examine the role of media in the voter's decision-making process. Lazarsfeld, Berelson, and Gaudet (1944) initially considered that elections are individual acts that are influenced primarily by voters' personality and media exposure. However, the results of that study, published in The People's Choice: How the Voter Makes His Mind in a 
Presidential Campaign, showed that a person's social community determines whom they will vote. The study found that the social and cultural environments were the main factors in influencing voter's behavior, and the relationship between a person's social community and voting behavior was strong. For example, the study showed that approximately $75 \%$ of firsttime voters voted for the same candidate as their parents (Lazarsfeld, Berelson, and Gaudet 1944, in Antwi, 2018).

Columbia School researchers asserted that voting choice is a matter of sentiment and attitude, not a rational choice. Their sociological model places a strong emphasis on external forces, especially the influence that the main group of voters exerts on them. A person becomes accustomed to the political tradition of the community they perceive (Heywood, 2002). Voter's behavior is seen as a product of the political and cultural environment.

The basic assumption of the sociological model is that a person's choice is more influenced by the expertise of the individual in a particular social community and the economic position of the social community (Heywood, 2002). Therefore, people who have the same identity in their social class, religion, region, or ethnicity tend to vote as a block, so choosing a particular candidate or party becomes the social extension of voters' identity (Andersen and Heath, 2003). As a result, social communities vote candidates or parties that are considered to represent their interests or prioritize their needs (Adjei 2012). Therefore, voter choice is a type of social activity. In simple terms, the social environment helps determine the publics' political compliance (Lazarsfeld, Berelson and Gaudet 1994 in Andersen \& Heath, 2003).

This approach states that the factors that most influence publics' choice in elections are social characteristics and groupings. The behavior of choosing someone is according to what their social community chooses (Roth, 2008). This fact means that social community determine a person's political inclinations. The social community referred to age, gender, religion, occupation, socio-economic class, regionalism, family background, and activities in formal and informal groups. In essence, a person's political choices are influenced by their social environment, not from their desires. These social communities are considered to be very dominant in influencing the decision because they play a large role in shaping a person's attitudes, perceptions, and orientation in life (Roth, 2008).

Another approach in assessing voter's behavior is a psychological approach. This approach stems from a survey study conducted by scholars at the University of Michigan during the U.S. presidential elections in 1948, 1952, and 1956. The combination of research results was published in the book entitled The American Voter by Campbell, Converse, Miller, and Stokes (1960). The psychological model offers a criticism of the sociological model. It combines both psychological and sociological factors to explain the election choice. Campbell, Converse, Miller, and Stokes (2010) emphasize that social communities' expertise does not directly influence a person's election decisions (Antwi, 2018).

While another model criticizes that the sociological model only relates social characteristics to voters' choice, so as a result, this process cannot be explained between them. In this case, the psychological model focuses on psychological variables that combine voters' eventual world output and their primary behavior (Campbell, Converse, Miller \& Stokes 1954). This model focuses on the cognitive motives of voters. Within this framework, three main "objects" were identified: political parties, political issues, and political candidates. This object is what voters see, assess, and respond to (Verburg, 1979 in Antwi, 2018). These three motivational factors are the main principles of the psychological model.

Psychological models underline party participation or identification as the most important determinant of voting behavior. Partisanship is defined as the psychological closeness and 
ongoing attachment of people to a particular political party (Campbell, Converse, Miller, \& Stokes 1960). Partisan voters are seen as loyal, long-term advocates who are well aware of political parties (Heywood, 2002). These strong ties make it challenging to convince partisan voters to vote for another party or even withdraw their support from the party of their choice. In this case, the identification of parties by voters is considered as a stable phenomenon that is not easily changed. For this reason, during elections, the choice of votes becomes a mere manifestation of old tendencies towards certain political parties. However, a voter's political engagement may change somewhat depending on the issues and candidates involved in a particular election (Campbell, 1964).

Besides the party system, issue orientation and candidate identification are two other motivational factors that influence voter's decisions based on this model. Issue orientation refers to individuals' perspectives and positions on issues and the extent to which voters' choice or dislike of specific policies affects their vote. For example, a voter concerned about immigration policy will vote the party that best represents his or her position on the issue. Conversely, candidate identification refers to the voter's interest in the candidate's personality. This also includes how voters perceive candidates, such as preferences. According to this approach, voters are also influenced by the personal traits of a leader, such as an attitude, style, and intelligence (Rabinowitz and Macdonald 1989 in Bartels 2012).

Social Community and Voter's behavior

Community is a group of people who have the same purpose and interact with each other to achieve the purpose, get to know each other, and see themselves as part of the group (Mulyana, 2007). Then DeVito (2002) in Saleh (2012) defines a group as an individual group that is relatively small, and they are associated with several purposes and has a certain degree of organization among them.

According to Horton and Hunt (1996) in Lukmana (2017), a social community is defined as a group of individuals who know their membership and interact with each other. According to Homans in Lukmana (2017), the social community is a group of individuals who do several activities and interactions and have feelings to form an organized and reciprocal unit. Soekanto in Soeroso (2008) states that social communities are associations of people who live together because they are mutually related and influence each other.

From the various explanations above, it can be concluded that social communities influence individuals' attitudes and behavior in their lives. Likewise, in a political context, especially elections, individual behavior in making voting decisions is also influenced by their social community. This is in line with the Columbia School view or the sociological approach of voter's behavior in Mujani (2012). Social community support has a significant role in shaping the attitudes, perceptions, and orientation of choosing someone. In many studies, religious factors, geographical aspects (regionalism), and class or economic status factors (especially in developed countries) have a real correlation with voter's behavior.

The basic assumptions of a sociological model state that a person's choice is more influenced by the expertise of individuals in a particular social community, as well as the economic and social position of the community (Anderson and Yaish 2003; Thomassen 1994; Heywood 2002). Therefore, people who have the same identity in social class, religion, region, or ethnicity tend to vote as a block, so choosing a particular candidate or party is an extension of the voter's social identity (Andersen and Heath, 2003 in Antwi 2018).

Another theory that explains that social communities influence voter's behavior is the theory of ethnic election. This theory explains that individuals behavior will follow the norms and values of the groups that belong to them. Therefore, a person's personality becomes identical 
to their social community. Thus, voters will choose a candidate from their social community if they consider the candidate to be the best protector for their interests (Adjei, 2013). According to Bratton, Bhavnani, and Chen (2012), ethnic voting occurs whenever members of a cultural community show disproportionate attachment to a particular political party's election.

In line with ethnic election theory, another social theory that explains individual and group behavior is social identity theory. Following Tjafel and Turner (1979), social identity is a sense of the individual possessed by a particular group or society. These groups are a source of extraordinary pride and self-respect, so people tend to increase their self-image by discriminating against "others" who are not part of the group (in Qorri, 2018).

There have been many studies on social communities' influence on voter's behavior, like a study conducted by Qorri (2018) entitled The Psychology Behind Voting Behavior in Kosova. This study aims to answer the question of what guides voter's behavior in Kosovo. The first hypothesis of this study is that rationality factors influence voters in Kosova. Second, he argued that social identity, family choice, gender bias, ideology, and emotions are significant in guiding voting behavior in Kosovo. This is seen through a combination of secondary and primary research, including a survey of 250 respondents and the Implicit Association Test (IAT). This study finding supported the idea that rational and irrational factors compete with each other when election decisions are made. Generally, irrational factors are the dominant factors, while rationality factors play a secondary role in this. Finally, the findings support the second hypothesis that ideology, social identity, gender bias, emotions, and family all play essential roles in influencing voter's behavior (Qorri, 2018).

The next study is conducted by Yustiningrum and Ichwanuddin (2014) entitled Political Participation and Voter's Behavior in the 2014 General Election. This study focuses on investigating how political participation and people's voting behavior in the 2014 General Election use sociological approaches, psychological approaches, and rational choice approaches. The study found that voters tend to choose candidates who adhere to the same religion as themselves. Apart from religious factors, promises to provide material assistance did not influence voters in determining their choice. However, for voters who are elderly, live in rural areas, and have less education, the promises of providing material assistance are a matter of consideration in casting their votes in the election. Regarding the voting behavior of first-time voters, Yustiningrum and Ichwanuddin found that they were more dominantly influenced by the choices of those around them, such as family and friends. Another finding from their study is regarding first-time voters' behavior, especially those living in rural areas, the majority of whom follow the attitudes of their parents or respected figures around them (Yustiningrum and Ichwanuddin, 2014).

A study by Papilaya and Rahmawati focused on examining the voter's behavior of the Kalideres community by using a sociological approach. Papilaya and Rahmawati investigated the relationship between religion, ethnicity, education, occupation, income, and residence area (Sociological choice indicators) on people's voting behavior. Besides, they also found out which sociological choice indicators have the most significant influence on the voting behavior of the voters in Kalideres on the DKI Jakarta 2017 regional election. The results of this study proved that there is a relationship between religion, ethnicity, education, occupation, income, and area of residence on the voting behavior of the voters in Kalideres and the most significant factor is religion (Papilaya and Rahmawati, 2017).

Apart from the study by Papilaya and Rahmawati, the writer also reviewed Hemay and Munandar's study. The study entitled the Voting Behavior of Identity Politics and the Imaging 
of Candidates for Governor. This study aimed to obtain a comprehensive picture of sociological factors' influence on voter's behavior of 2015 regional election in Bengkulu. This study revealed that "strategic factors such as programs and policies offered by a candidate for governor which are seen as providing greater benefits for the publics' interest, for the sake of creating a prosperous society, are things that may have more influence on voter's behavior. This means that, once again, voters' preferences for governor candidates are mostly shaped by rational factors and not by primordial factors such as ethnicity and other primordial ties. This time, Bengkulu's voter's behavior cannot be influenced by ethnic identity politics, prioritizing tribal sentiments over logical considerations. This shows the character of Bengkulu voters as critical and responsible" (Hemay and Munandar 2015). From this study, we can understand that sociological factors do not always positively influence voter's behavior.

A study by Sarlamanov and Jovanoski (2014) explained that family social communities are the dominant agents of socialization that influencing vote choices. Culture, values, and political norms of the old generation are passed on to the younger generation through the socialization of politics (Sarlamanov and Jovanoski, 2014). This socialization is most substantial in childhood when most political attitudes are formed. In this initial ranking, the fundamental values that determine voters' political life are studied in the family, primarily through the relationship between parents and children. Therefore, individuals inherit their families' political choices and tend to vote as their families do (Sarlamanov and Jovanoski, 2014).

\section{Psychological Factors and Voter's Behavior}

Psychological factors in political studies (elections) are factors that influence in shaping voter's behavior in decision making. As explained by Campbell, Converse, Miller, and Stokes (1954) in Antwi (2018) about the psychological model states that psychological variables have an intervention in shaping behavior that connecting the voter world's external events and their primary behavior. This model focuses on the cognitive motives of voters. Within this framework, there are three main objects of psychological factors: identifying parties, identifying political candidates, and identifying political issues. Venburg (1979) explained that this object is what voters see, assess, and respond to (Antwi, 2018). These three motivational factors are the main principles of the psychological model.

Party Identification

According to the Language Center of the Ministry of National Education (2016), identification is a psychological process that occurs in a person because he unconsciously imagines himself as someone else then he behaves like someone he admires. According to Chaplin (2008), identification is the process of knowing, positioning an object or individual into a class according to certain characters.

In general, it can be said that a party is an organized group whose members have the same orientation, values, and ideals. This group aims to gain political power and constitutionally seize political position to implement its program (Budiardjo, 2008). Friedrich defines the party as a group of organized people intending to seize or maintain control of the kingdom for the party's leadership and, based on this control, giving party members ideal and material benefits. Then Neumann, in his book, Modern Political Parties, states that the definition of a party is an organization of political activists who try to control government power and win popular support through competition with other groups or groups that have different views (in Budiardjo, 2008) 
Party identification is defined as psychological closeness and individual self-identification to a particular party (Grenee, 1999). Furthermore, according to Dalton, Flanagan, \& Beck (1984), the definition of party identification is the psychological relationship between individuals and the parties they support (in Grenee, 1999). From some of the definitions above, it can be concluded that party identification is a psychological process in assessing a particular party, which causes closeness and tends to encourage behavior towards the party or object identified.

Greene (1999) suggested three different sources of attitudes towards parties, namely, emotional closeness to parties (partisan effects), party beliefs (partisan cognitions) and feelings of belonging to the party (sense of belonging), and party social identification. The three components are independent and interact with each other in influencing political attitudes and behavior. This study also adds that an ideological component as the basis for voters to identify parties. Abramovich and Saunders (2006) state that ideology is very important to consider because it affects party identification. Although there are different ways of defining ideology, political scientists generally view ideology as a set of beliefs in the role an organization should play, which then shapes a response to various forms of political policy that have a broad scope (Converse in Abramovich and Saunders, 2006).

One of the roles of party identification is to form a viewpoint that becomes a filter on political information about parties that are chosen by individuals (Campbell, 1960). In other words, this perspective acts as an individual schema in political matters. Party identification can also influence voting directly or indirectly through the evaluation of issues and candidates supported by political parties (Greene, 1999). Schmitt \& Holmberg (1995) states that party identification will stabilize the behavior of individual party voters. If the level of party identification decreases, individual behavior's stability element will decline (in Mujani, 2007). When party identification decreases, the behavior of alternating party choices (electoral volatility) will tend to increase.

Haryanto conducted a study on the effect of party identification on voter's behavior. The study, entitled The Awakening of Party ID; Analysis of Voter's Behavior in Indonesian Local Politics, this study tries to see voter's behavior using a psychological approach. The results of his study showed that voters no longer vote based on sociological factors but are influenced by psychological factors such as voters tend to identify themselves with the party, then determine their choice of votes to candidates nominated by parties considered close to themselves (Haryanto, 2014).

The next study is from Bonneau and Cann (2015); the theme of this study is Party Identification and Vote Choice in Partisan and Nonpartisan Election. In his study, he was interested in the effect of party identification on vote choices. Indeed, a coalition of parties supporting a candidate is seen as the most meaningful clue to voters regarding which candidate they should support. However, many elections in the U.S. does not take sides. By using both experimental data and the first national survey of voters in the election of judges. This study indicates that voter's decisions are strongly influenced by party identification in partisan and nonpartisan elections.

Then Apriani (2012) also conducted a study entitled The Influence of Party Identification Factors and Candidate Factors on Voting Behavior in the 2010 General Election of TabananBali Regency. Besides, there is a big difference between previous studies' results and the results of this local Tabanan election. The candidate who proved to have the highest electoral ability because of his excellent leadership in society was defeated by the female candidate who only had $5.7 \%$ electability. This study was conducted to answer how political parties and 
candidates' factors influence the voting decision for the Tabanan area. As a theoretical basis, this study uses the theory of voting behavior, especially the psychological approach. The method used in this research is the quantitative method. This study uses primary and secondary data. The sample used in this study is 400 respondents. Therefore, the interval is 95\% sure, and the margin of error is 5\%. Data found in the field showed that in the 2010 Tabanan regional election, the community's party identification factor, especially the PDIP, influenced voter's behavior. Meanwhile, the candidate's personality factor also affects but is not a significant factor in the election in Tabanan.

Candidates Identification

Candidate identification has the same concept as party identification. The more often the voter's positions himself against the existing candidates, the more likely it is to participate in the election. The closer the voters' views candidates from a particular party, the more likely they will vote for that candidate (Roth, 2008).

Then Bone and Ranney (1981) in (Nursal, 2004) said that identifying a candidate means that people choose a leader candidate based on the candidate's instrumental and symbolic qualities. Instrumental quality is the voter's belief in the candidate's personal ability to bring good to society to be led. Meanwhile, symbolic quality refers to the personality of a candidate that a leader should have. Nursal (2004) emphasized that figures' quality often determines choice decisions than issues because people are more receptive to factual information about humans than facts about issues.

Identification of candidates can also be seen from the voters' assessment of the candidate's image. De Vries (2008) argued that based on the perspective of political communication and political psychology, the image of a candidate can be seen from 5 aspects, namely: sympathy or the ability to understand the environment emotionally, the trustworthiness of candidates, leadership capacity or leadership qualities of candidates, physical attractiveness or the candidate's physical condition and competence or ability of the candidate in carrying out the task.

Antwi (2018) conducted a study on party identification and voter's behavior with the title How Do Voters Decide? A Study of The Determinants of Voting Behavior in Ghana. This study aimed to determine the factors that influence voter's behavior in Ghana. Antwi used a survey method that was carried out in four regions in Ghana. The results of descriptive analysis and logistic regression of the data show that the candidates' personality and campaign promises are the most important predictors of vote choice. The study further found that ethnic and economic variables are small features of voter's behavior in Ghana. They do not influence the majority of voters in making voting decisions. This finding contradicts the conventional view of the Ghanaian election, which considers voters to be influenced only by ethnic groups. Besides, the findings show that most Ghanaians are voters who make voting decisions after careful assessment of the competence of the competing candidates and campaign promises. Overall, this study draws attention to the interests of personality and pragmatic policies in winning elections. Therefore, politicians should be concerned about people's perceptions of their credibility and image and the policies they bring to the campaign platform (Antwi, 2018). Another study by Koppensteiner and Stephen (2014) examined the relationship between voters' first impressions and the tendency to choose candidates who are considered to have personal characteristics close to or similar to voters. Eighty participants were recruited at the University of Vienna as the object of study. During their experimental study, respondents were asked to rate themselves, and the unknown politician presented to them in a short video clip containing a speech. Then the participants were asked to assess the probability they 
would vote for each politician they saw. The study found that participants tended to vote for politicians thought to have similar personality traits to voters. It also states that first impressions can influence participants' choices. This study proves that voters give political candidates votes with certain personality traits that they want (Koppensteiner and Stephen, 2014).

Besides from Koppensteiner and Stephen, Nwanganga, Nwachukwu, and Mirian (2017) also studied candidates' identification with voter's behavior. They examined the influence of personality traits on voter's decisions before and during the 2015 presidential election in Nigeria. They recruited 400 eligible voters from the six geo-political zones in Nigeria. Respondents were given a set of structured and open questionnaires about the personality and naming of candidates. The study results showed that the dimensions of personality, such as proficiency, credibility/sincerity, are characteristics that influence the choice of political candidates for voters before and during the election period.

\section{Issue Identification}

As well as the identification of parties and candidates, the same logic applies to identifying issues. Roth (2008) states that the identification of an issue is the more voters consider specific issues necessary, the more likely they will continue to participate in a more significant election. Conversely, if the solution provided by a party or candidate is closer to the voter's perspective, the more he will vote for that party (Roth, 2008).

Then to find out whether voters feel following the issues raised by parties or candidates, Roth (2008) explains that specific issues will be able to influence voter's behavior if they meet the following three requirements: (1) the issue can be caught by voters; (2) the issue is considered necessary by voters; (3) voters can classify their position on the issue, either positive or negative (Roth, 2008).

\section{Conclusion}

In this section, the authors try to synthesize several existing literature reviews on the factors influencing voter's behavior in elections. There are differences in voter's behavior in various regions. From one region to another, they do not have the same voting behavior as studies that have been conducted in the United States, Ghana, Nigeria, Kosova, or Indonesia, which have different voter's behavior. The factors that influence the decision to choose are very diverse, not only determined by one factor. Some choose based on sociological factors such as social community, family, ethnicity, and religion and are also influenced by psychological factors such as identifying political parties, identifying candidates, and identifying issues.

This is in line with what Prysby and Scavo conveyed, that the decision to choose does not occur in a vacuum or happens by itself, but rather that decision making is based on a person's life experience. Many factors influence voters' choice (Hazarika, 2015). The study results show that voters can determine their vote based on one or more considerations (Prysby and Scavo 1993; Hazarika, 2015).

Besides, another conclusion is to read the voter's behavior in an area that should use various perspectives. As explained earlier, the theoretical approach in reading voter's behavior is a sociological approach that emphasizes the dominant social factors that influence individuals in determining their political choices. The psychological approach also underlines that psychological factors or individual cognitive aspects are more dominant in determining voter's behavior. Even though the psychological approach is based on criticism of the sociological point of view (Antwi, 2018), it does not mean that it is more accurate than the 
sociological approach. Vice versa. Each perspective will be relevant depending on the conditions of each community in one area. As explained before, the two approaches do not have to be viewed or judged as more accurate. However, they must be interpreted as a tool for the reviewer to get a comprehensive picture of voter's behavior by looking at the various possible factors or reasons that influence it.

There are many understanding or awareness of differences in voter's behavior. For that reason, the writers need to use multiple perspectives to explain voter's behavior. The writers hope many definitions of voter's behavior will become the basis for related parties such as the KPU, political parties, and politicians in assessing and making strategies to increase the political participation of the community.

\section{References}

Abramovich, A. L., Saunders, K. L. (2006). Exploring Bases of Partisanship in American Electorate: Social Identification vs Ideology. Political Researh Quarterly.

Adjei, J. K. (2013). Ethnicity and Voting Behavior in the Ashanti and Volta Regions of Ghana: A Cramp in the Wheel of a Fledgling Democracy?. Journal of Global Initiatives: Policy, Pedagogy, Perspective, 7(1), 1-14.

Antwi, B. R. (2018). How Do Voters Decide ? A Study of The Determinants of Voting Behavioor in Ghana. International and Comparative Politics Graduate Program, School of Public and International Affairs. Wright State University; Ohio.

Andersen, R., \& Heath, A. (2003). Social Cleavages, Attitudes and Voting Patterns: A Comparison of Canada and Great Britain. Working Paper, (81), CREST (Center for Research into Elections and Social Trends).

Andersen, R., \& Yaish, M. (2003). Social Cleavages, Electoral Reform and Party Choice: Israel's 'Natural' Experiment. Electoral Studies, 22(3), 399-423.

Apriani, D. K. (2012). Pengaruh Faktor Identifikasi Partai Politik dan Faktor Kandidat Terhadap Perilaku Memilih Dalam PEMILUKADA Tabanan-Bali Tahun 2010. Departemen Ilmu Politik, Program Pascasarjana Universitas Indonesia.

Bartels, L. M. (2012). The Study of Electoral Behavior dalam Jan E. Leighley (ed) The Oxford Handbook of American Elections and Political Behavior. Oxford: Oxford University Press.

Bonneau, C., \& Cann, D. (2015). Party Identification and Vote Choice in Partisan and Nonpartisan Election. Political Behavior, 37, 43-66.

Bratton, M., Bhavnani, R., \& Chen, T. H. (2012). "Voting Intentions in Africa: Ethnic, Economic or Partisan?" Commonwealth \& Comparative Politics. Vol. 50. No.1.

Budiardjo, M. (2008). Dasar-Dasar Ilmu Politik. Jakarta:Gramedia Pustaka Utama.

Campbell, A., Converse, P. E., Miller, W. E., \& Stokes, D. (1960). The American Voter. Chicago: University of Chicago Press.

Chaplin, J. P. (2008). Kamus Lengkap Psikologi. Jakarta: PT Raja Grafindo.

De Vries, J. (2008). The Industious Revolution: Consumer Behavior and The Household Economy, 1650 to The Present. Cambridge: University Press.

Diamond, L., Linz, J., M. S., \& Lipset. (1990). Politics in Developing Countries: Comparing Experiences with Democracy. Boulder CO: Lynne Rienner Publishers.

Efriza. (2012). Political Explore: sebuah kajian ilmu politik. Bandung: Alfabeta.

Friedman, T. L. (2010). A Tea Party Without Nuts. Retrieved from http://www.nytimes.com/2010/03/24/opinion/24friedman. html

Greene, S. (1999). The Pshycological Structure of Partisanship; Affect, Cognition and Social Identity in Party Identification. Columbus; The Ohio State University. 
Haryanto. (2014). Kebangkitan Party ID; Analisis Tingkah laku pengundi dalam Politik Lokal Indonesia. Jurnal IImu Sosial dan IImu Politik, 17(3), 291-308.

Hazarika, B. (2015). Voting Behavior in India and its Determinants. IOSR Journal of Humanities and Social Science (IOSR-JHSS), 20(10), 22-25.

Hemay, I., \& Munandar, A. (2016). Politik Identitas dan Pencitraan Calon Gubernur Terhadap Perilaku Memilih. Jurnal Kajian Politik dan Masalah Pembangunan, 12(1). 1737-1748.

Heywood, A. (2002). Politics (Edisi 2). New York: Palgrave.

Kementerian Pendidikan Nasional. (2016). Kamus Besar Bahasa Indonesia (KBBI). Jakarta: Balai Pustaka.

Koppensteiner, M., \& Stephen, P. (2014). Voting for a Personality: Do First Impressions and Self Evaluations Affect Voting Decisions? Journal of Research in Personality. 51, 62-68.

Lukmana, H. B. (2017). Hubungan antara Dukungan Kelompok Sosial dengan Perilaku Pemilih Pada Pemilihan Kepala Daerah Kabupaten Sukoharjo Tahun 2015. Jurnal Sosiologi DILEMA, 32(1), 1-8.

Mujani, S. (2007). Muslim Demokrat: Islam, Budaya Demokrasi dan Partisipasi Politik di Indonesia Pasca Orde Baru. Jakarta: PT Gramedia Pustaka Utama.

Mujani, S., Liddle, W., \& Ambardi, K. (2012). Kuasa Rakyat. Jakarta: Mizan Publika.

Mulyana, D. (2007). Ilmu Komunikasi: Suatu Pengantar. Bandung: Remaja Rosdakarya.

Nursal, A. (2004). Political Marketing: Strategi Memenangkan Pemilu.Jakarta: Gramedia.

Nwanganga, A., P., Nwachukwu, C. P., \& Mirian, U. (2017). Political Branding/Brand Personality and Voter's Choice of Candidate: An Empirical Inquiry into 2015 Presidential Election in Nigeria. Journal of Marketing and Consumer Research. 37, 1-15.

Papilaya, A., \& Rahmawati, R. (2018). Pengaruh Pilihan Sosiologi Terhadap Perilaku Memilih Masyarakat Kecamatan Kalideres Jakarta Barat Pada Pilkada Jakarta 2017. JIIP, Vol. 4(1), 1-14.

Roth, D. (2008). Kajian Pemilu Empiris: Sumber, Teori, Instrumen, dan Kaedah, terjemahan. Jakarta: Friedrich-Naumann Stiftung fur die Freiheit.

Sarlamanov, K., \& Jovanoski, A. (2014). Models of Voting. Researchers World, 5(1), 16-24.

Saleh, A. (2012). Kumpulan Bahan Kuliah Manajemen Kelompok dan Organisasi. Bogor. Program Studi Ilmu Penyuluhan Pembangunan, Sekolah Pascasarjana IPB.

Surbakti, R. (2010). Memahami Ilmu Politik. Jakarta: PT.Grasindo.

Soeroso, A. (2008). Sosiologi 2. Jakarta; Penerbit Quadra.

Qorri, F. (2018). The Psychology behind Voting Behavior in Kosovo. Thesis. Rochester Institute of Technology. Retrieved from http://scholarworks.rit.edu/theses

Yustiningrum, E., \& Ichwanuddin, W. (2014). Partisipasi Politik dan Perilaku Memilih pada PEMILU 2014. Jurnal Penelitian Politik, 12(1), 117-135.

BBC News. (2019). Lembaga Survei: Jumlah Golput di Pilpres 2019 Paling Rendah Sejak 2004. Retrieved from https://www.bbc.com/indonesia /indonesia-48130161.amp

Kumparan. (2018). Tim Jokowi Soroti Kenaikan DPT dari Pemilu 2004 ke 2019 yang Stagnan. Retrieved from https://m.kumparan.com/amp/kumparan news/tim-jokowi-sorotikenaikan-dpt-dari-pemilu-2004-ke-2019-yang-stagnan-1542365929685043032 